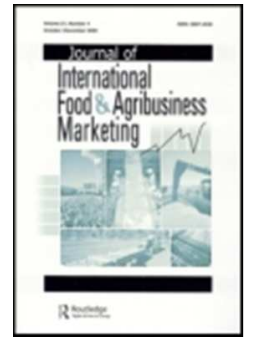

\title{
Who eats seaweed? An Australian perspective
}

\begin{tabular}{|r|l|}
\hline Journal: & Journal of International Food \& Agribusiness Marketing \\
\hline Manuscript ID & WIFA-2018-0057 \\
\hline Manuscript Type: & Institute of Food Products Marketing Research Conference \\
\hline Keywords: & Seaweed consumption, Australia, consumer behaviour, drivers, barriers \\
\hline \multicolumn{2}{|c}{} \\
\hline
\end{tabular}

SCHOLARONE ${ }^{m}$

Manuscripts 


\title{
Who eats seaweed? An Australian perspective
}

\begin{abstract}
Current seaweed consumption, and attitudes and preferences towards seaweed food products in a Western society are investigated to inform the seaweed industry regarding product development and marketing strategies. A national survey of 521 Australian consumers was conducted. About $75 \%$ of respondents had eaten seaweed, however only $37 \%$ had consumed seaweed regularly over the past 12 months. Key drivers include health and nutritional benefits, taste, and being natural, safe and fresh. Critical barriers are lack of knowledge and familiarity, and the perception that seaweed is expensive. Females and younger, health conscious consumers with higher household incomes and levels of education, who are more adventurous with food (neophilic), and who tend to snack and assign symbolic value to food are more likely to consume seaweed. Recommendations for the emerging seaweed industry in terms of target markets and relevant marketing strategies are presented and areas of further research proposed.
\end{abstract}

Key words: seaweed consumption; Australia; consumer behaviour; drivers; barriers 


\section{Who eats seaweed? An Australian perspective}

\section{Introduction}

While not being a part of the traditional diet, seaweed is becoming increasingly popular in Western societies, featuring in television cooking shows, restaurant menus, food blogs and recipe books and websites. Internationally renowned UK chef Jamie Oliver recently described seaweed as "the most nutritious vegetable in the world" and devoted an entire episode of his television cooking show “Jamie and Jimmy's Friday Night Feast" to seaweed (Matthews, 2018). Seaweed consumption, in particular that associated with sushi and as an ingredient in snack foods, such as seaweed flavoured crackers, has experienced significant growth in recent times (Altintzoglou, Heide, Wien, \& Honkanen, 2016). Of the estimated 12,000 species of seaweed across the globe, about 500 are currently used for human consumption (Prager, 2017). While consumers in Asian countries frequently consume seaweed, it is typically not part of the traditional diet for most Western countries (Brownlee, Fairclough, Hall, \& Paxman, 2012; Chapman, Stevant, \& Larssen, 2015; Fleurence, 2012; Prager, 2017). There is, however, growth in the seaweed food market in Western societies. In the UK, for example, more than 200 different seaweed food products can be purchased, of which $63 \%$ are produced from locally UK sourced seaweed (Bouga \& Combet, 2015). Likewise, there are opportunities for the growth of the seaweed industry in other typically Western societies, such as Australia.

Australia has an extensive coastline with over 6,000 different varieties of seaweed, representing a significant opportunity to take advantage of the growing popularity of seaweed by making domestic products. However, before making substantial investment, the emerging seaweed industry needs to develop an understanding of consumers' perceptions of seaweed as a food product and hence, demand and preferences. Gaining acceptance of unfamiliar food 
products, such as seaweed, which some consumers may find confronting, will be challenging and thus consumer insight is critical for developing appealing product offerings and developing appropriate branding strategies.

Little is known about Western consumers' attitudes towards seaweed as a food product other than inferential data from the categories of product available for purchase. A search of extant literature revealed very few articles examining consumers and seaweed. In 2017, Prager (2017) published a conceptual article focusing on consumers' perceptions of seaweed food products, and prior to this, Chapman et al. (2015) reported on the potential for including seaweed enhanced products in the Nordic diet. This research aims to address this gap in the body of knowledge by investigating current seaweed consumption and preferences, and understanding consumers' behaviour toward seaweed, along with drivers and barriers of seaweed consumption in one typical Western society, namely Australia.

\section{Drivers and barriers of seaweed consumption}

\section{Health and nutritional benefits}

Consumers are increasingly more health-conscious, with research indicating that women tend to be more health-conscious than men (Beardsworth et al., 2002; Fagerli \& Wandel, 1999; Gould, 1988; Kubberød, Ueland, Rødbotten, Westad, \& Risvik, 2002; Verbeke, 2005). Seaweed is a functional food that delivers numerous health benefits, including improved digestive track and bone health, and aids prevention of chronic conditions and diseases, such as cardiovascular disease, cancer, diabetes and metabolic syndrome (Bouga \& Combet, 2015). There is now clear evidence that the edible varieties of seaweed are highly nutritious, rich in antioxidants and contain beneficial micronutrients (Bouga \& Combet, 2015; Gupta \& Abu-Ghannam, 2011; Roohinejad et al., 2017). In addition, seaweed is high in dietary fibre 
and has been found to aid weight loss through enhanced satiety and reduced fat absorption leading to lower risk of cardiovascular disease (Brownlee et al., 2012; Hall, Fairclough, Mahadevan, \& Paxman, 2012). However, little is known about Western consumers' understanding of the potential health and nutritional benefits of seaweed or how they could be delivered via various seaweed product lines.

\section{Responsibility with food and food safety concerns}

In addition to a desire for healthier food, consumers are also becoming increasingly conscious of where their food comes from and how it is produced (Pieniak, Verbeke, Scholderer, Brunsø, \& Olsen, 2008). For example, studies of fish consumption have indicated that some consumers are concerned about risks associated with seafood consumption due to chemical and bacterial contamination, and the possibility of being allergic or getting ill from eating fish (Pieniak et al., 2008). Likewise, concerns about food safety associated with seaweed include the potential presence of allergens and pathogens (van der Spiegel, Noordam, \& van Der Fels-Klerx, 2013). However, allergens linked to seaweed are rare as compared to fish (Fleurence et al., 2012). There are some risks of toxicity from seaweed consumption linked to high iodine levels, arsenic, heavy metals and contaminants, for example, high levels of arsenic in brown seaweed (Food Standards Australia New Zealand, 2013, 2016). However, these risks are easily mitigated through monitoring of seaweed species and the water within which it is produced (Bouga \& Combet, 2015). 


\section{Environmental benefits}

Concerns that diets high in red meat lead to health risks, and the associated environmental impacts of livestock farming (e.g. climate change, greenhouse emissions, arable land usage, water usage, etc.), have encouraged consumers to consider replacing meat with healthier, more sustainable and ethical protein, including plants, insects and seaweed (Aiking, 2011; Arioli, Mattner, \& Winberg, 2015; de Boer, Schösler, \& Boersema, 2013; Duarte, Wu, Xiao, Bruhn, \& Krause-Jensen, 2017; Fleurence et al., 2012; Prager, 2017; Verbeke, 2015). For example, research conducted by Mintel (2016) revealed that $58 \%$ of German consumers and $44 \%$ of UK consumers had "either tried or would like to try algae as a protein source". Not all species of seaweed will be appropriate substitutes as the protein content varies considerably (A. Angell, S. Angell, de Nys, \& Paul, 2016; Angell, Mata, de Nys, \& Paul, 2016). For instance, protein content can be up to $47 \%$ in the nori species used for sushi (Warwicker \& Taylor, 2012).

\section{Sensory characteristics}

Taste is a key driver of food choice and has been attributed to increased interest in seaweed as a food (O. Mouritsen, Johansen, \& J. Mouritsen, 2013; Tan, Fischer, van Trijp, \& Stieger, 2016; Tinellis, 2014). Different species of seaweed have different sensory profiles and respond differently when cooked or processed (Chapman et al., 2015). However, adding seaweed to traditional Nordic dishes, for example, did not negatively impact flavour and even revealed potential for improving texture, appearance and the colour of foods (Chapman et al., 2015). Conversely, other studies have found that the addition of seaweed reduces product acceptability (Fernández-Martín, López-López, Cofrades, \& Colmenero, 2009; JiménezColmenero et al., 2010). Research indicates that consumers typically report reduced sensory 
appeal for less familiar or novel foods (Arvola, Lähteenmäki, \& Tuorila, 1999; Raudenbush \& Frank, 1999). Consumers may reject an unfamiliar food, such as seaweed, based purely on its appearance and smell, or due to what Tan et al. (2016) describe as negative "non-sensory associations" (e.g. it is "simply gross").

\section{Lack of familiarity and neophobia}

Food consumption is highly habitual, complex and multidimensional (Brunsø, Verbeke, Olsen, \& Jeppesen, 2009; Köster 2009). Consumer familiarity with a food category reduces uncertainty and perceived risk associated with the potential negative effects of consumption and reduces consumers' scepticism of a product category (Borgogno, Favotto, Corazzin, Cardello, \& Piasentier, 2015; Verbeke, Scholderer, \& Lähteenmäki, 2009). Hence, despite evident health and environmental benefits, getting consumers in Western societies to replace traditional meats with alternative and unfamiliar sources of protein such as seaweed will be challenging (Chapman et al., 2015; Prager, 2017; Schösler, de Boer, \& Boersema, 2012).

Neophobia or the unwillingness to try new or unfamiliar foods results in high failure rates for innovative food products (Barrena \& Sánchez, 2012; Gresham, Hafer, \& Markowski, 2006; Moreau, Lehamann, \& Markman, 2001; Pliner \& Hobden, 1992; Tuorila, Meiselman, Bell, Cardello, \& Johnson, 1994). Neophobia has been found to differ across age groups, with lower levels of neophobia associated with younger people (Loewen \& Pliner, 2000; Tuorila, Lähteenmäki, Pohjalainen, \& Lotti, 2001); more educated consumers (Flight, Leppard, \& Cox, 2003); males (Meiselman, Mastroianni, Buller, \& Edwards, 1999; Nordin, Broman, Garvill, \& Nyroos, 2004); and urban consumers as compared to rural consumers (Flight et al., 2003; Tuorila et al., 2001). 


\section{Perceptions of affordability and availability}

Price and lack of perceived availability are common barriers to consumption of fresh seafood (Trondsen, Scholderer, Lund, \& Eggen, 2003) and fresh fruit and vegetables (HaynesMaslow, Parsons, Wheeler, \& Leone, 2013). Novel foods are typically less readily available and are often perceived to be exclusive and more expensive, thus representing higher purchase costs (i.e. price and effort) for the consumer leading to lower perceptions of customer value (Papista \& Kyrstallis, 2013; Perrea, Krystallis, Engelgreen, \& Chrysochou, 2017). For example, Verbeke, Sans and van Loo (2015) found that price along with sensory expectations explained consumer lack of acceptance of cultured meat as an alternative source of protein.

\section{Propensity to snack}

Demand for convenient snacks with nutritional and functional benefits has increased in recent times (Potter, Stojceska, \& Plunkett, 2013; Rathod \& Annapure, 2016). Snacks are a strong growth market estimated to be valued globally at US $\$ 635$ billion by 2020 , with an increasing demand for functional, organic and natural snacks (Global Industry Analysts, 2015). This propensity for seeking convenient, healthier snack foods represents a real opportunity to introduce seaweed into the Western diet. A research report from Mintel (2016) revealed that food and drink product launches with seaweed flavours increased by $147 \%$ in Europe between 2011 and 2015, with $37 \%$ of these products being in the snack category. 


\section{Symbolic value}

Consumption of certain "trendy" or novel foods can serve an image and social "status" function, and thus seaweed consumption may have some symbolic value for the consumer (Elliot, 2014; Jain \& Srinivasan, 1990; Laurent \& Kapferer, 1985; Perrea et al., 2017). For example, Brunsø et al. (2009) found that Belgians considered cooking fish to be "chic", and Juhl and Poulsen (2000) suggested that "it tells something about a person if he/she eats fish". A comparison of Norwegian and Japanese sushi consumers revealed that in addition to health benefits and convenience, eating sushi is considered to be "trendy" (Altintzoglou et al., 2016).

Given the lack of literature on the subject of seaweed consumption, an exploratory model of seaweed consumption (Figure 1) was developed to guide this inquiry. In this research, it is proposed that consumers' intentions to consume seaweed will drive consumption frequency. Consumption frequency and purchase intentions will be associated with key drivers and barriers. However, this association will be mediated by psychological influences over seaweed consumption, including health-consciousness, responsibility with food and concerns about food safety, neophobia, snacking behaviour and symbolic value. It is also proposed that demographic differences may influence purchase intentions and, therefore, seaweed consumption frequency.

INSERT Figure 1: An exploratory model of seaweed consumption. 


\section{Materials and Methods}

\section{Data collection and sample}

A national online survey of Australian consumers $(n=521)$ was administered in November 2017 through a professionally managed Qualtrics online consumer panel (Qualtrics Pty Ltd, Sydney). Because the Qualtrics panel sample is not a "probability sample", meaning that it will not provide a national representation, we aimed for at least 500 respondents to ensure that there were sufficient numbers $(>100)$ in each age demographic. The survey took approximately 15 minutes to complete. The survey contained questions regarding current seaweed consumption, attitudes towards seaweed as a food product, perceptions of benefits and risks, drivers and barriers to seaweed consumption, preferences and consumption occasions.

A profile of the respondents is provided in Table 1. Given respondents were screened for being at least a joint grocery shopper for the household, responses are skewed towards females. In line with the ethnic make-up of the Australian society, nearly three-quarters of the respondents (73.5\%) identified as white Australian, 8.8\% identified as being Asian, and 7.1\% as European.

INSERT Table 1: Respondent profile.

\section{Questionnaire and scaling}

In order to distinguish seaweed consumption from sushi consumption, which we suspected was the most prominent form of seaweed consumed in Australia, the respondents were first introduced to the purpose of the survey. After responding to socio-demographic 
questions, a series of open-ended questions related to seaweed were asked (i.e., "What is the first thing that comes to mind when you hear the word "seaweed"?, "Complete the following sentences: "When I think about eating seaweed, I ...", and "Eating seaweed is ...". The wide range of responses indicate that the respondents were or became aware of seaweed as a wider food category than just sushi wrappings (i.e., as a proxy for self-reported familiarity).

Seaweed consumption was measured on three variables: (1) Have you ever eaten or tasted seaweed? (Yes/No); (2) How often seaweed was consumed in the past 12 months (ranging from never to daily); and (3) Likelihood to consume seaweed in the next 12 months (7 point scale). We asked respondents if they were aware that sushi wrappers were made from seaweed.

To better understand the market for seaweed, relevant constructs such as neophobia, healthconsciousness, responsibility with food and concern about food safety, symbolic value when making food choices, and snacking behaviour were measured. Food neophobia was measured on four items, with three selected from Pliner and Hobden's (1992) Food Neophobia Scale (FNS) and one item from the original Food Related Lifestyle (FRL) instrument (Brunsø \& Grunert, 1995). To measure health consciousness, four items were selected from Gould's (1990) health-consciousness scale. Responsibility with food and food safety concern items were based on items from the Modular Food Related Lifestyle (MFRL) Instrument currently under scale development (Birch, Brunsø, Grunert, \& Memery, 2017). To measure symbolic value, three items were used from Laurent and Kapferer's (1985) and Jain and Srinivasan's (1990) consumer involvement profile (CIP) scales. Measures for snacking behaviour were based on three items in the original FRL instrument (Brunsø \& Grunert, 1995). The items are shown in Appendix 2. 
Based on the literature and media articles about benefits and risks of seaweed consumption, respondents were also asked to indicate on a five point Likert-type scale the relevance of a range of reasons for eating or not eating seaweed (Tables 7-8).

Exploratory factor analysis was conducted on the 25 psychological influence items. After removing six non-discriminant and non-converging items, five factors were retained with Cronbach's Alpha values ranging from .85 to .88 (see Appendix 2). Summated scales were made from the factors and used in the subsequent analyses. Statistical analyses were performed using the statistical software SPSS Version 24. Bivariate analyses includes cross tabulation with chi-square statistics and independent sample T-tests.

\section{Results}

\section{Seaweed Consumption}

For analysis purposes, respondents who indicated that they did not know if they had eaten seaweed were removed. Most of the respondents (83.9\%) were aware that sushi wrappers were made from seaweed. Of those respondents who were sure that they had or had not eaten seaweed $(n=502)$, nearly three quarters $(74 \%)$ reported that they had eaten or tasted seaweed (Table 2). Consumption frequency of seaweed is relatively low with only $37 \%$ of the respondents eating seaweed more than once a month in the past 12 months. However, $62 \%$ indicated that they would be likely to eat seaweed in the next 12 months. Those who had eaten or tasted seaweed in the past were more likely to eat seaweed in the next 12 months $(77 \%)$ than those who had not tasted seaweed in the past $(8 \%)\left(\chi^{2}=149.84, p=.000\right)$. The demographic differences associated with seaweed consumption were then tested (Table 2). 
INSERT Table 2: Demographic differences associated with seaweed consumption.

There were no differences on the basis of gender for having eaten or tasted seaweed or for the likelihood of consuming seaweed in the next 12 months. However, more females (41\%) than males $(32 \%)$ reported having consumed seaweed more than once per month in past 12 months $\left(\chi^{2}=4.52, p=.03\right)$. Respondents with the main role of shopping and cooking for their household were more likely to have eaten or tasted seaweed $(76 \%)$ than those who indicated a joint role $(66 \%)\left(\chi^{2}=4.08, \mathrm{p}=.04\right)$. However, there were no differences with respect to frequency of consumption in the past 12 months or the likelihood of consuming seaweed in the next 12 months on the basis of shopping and cooking role.

More highly educated people were more likely to have eaten or tasted seaweed $\left(\chi^{2}=9.84, p=\right.$ $.02)$, had consumed seaweed more frequently in the past 12 months $\left(\chi^{2}=25.57, p=.00\right)$, and were more likely to consume seaweed in the next 12 months $\left(\chi^{2}=21.90, p=.00\right)$. People with higher household incomes were more likely to have eaten or tasted seaweed $\left(\chi^{2}=19.07\right.$, $p=.00)$, had consumed seaweed more frequently in the past 12 months $\left(\chi^{2}=17.01, p=.00\right)$, and were more likely to consume seaweed in the next 12 months $\left(\chi^{2}=9.24, p=.03\right)$. Younger people were more likely to have eaten or tasted seaweed $\left(\chi^{2}=12.09, \mathrm{p}=.01\right)$, and to have consumed seaweed more frequently in the past 12 months $\left(\chi^{2}=20.62, p=.00\right)$. However, younger consumers were no more likely to consume seaweed in the next 12 months than older consumers.

Respondents were asked to indicate what seaweed products they had consumed (Table 3) and which products they would be willing to eat. The most commonly consumed seaweed product is sushi $(70.6 \%)$, followed by seaweed flavoured crackers $(48.6 \%)$, seaweed soup $(35.3 \%)$, 
and seaweed flavoured snacks (22.6\%). Less frequently consumed seaweed products include fresh seaweed in a salad (18.8\%) and seaweed flakes or sprinkles (13.6\%). Seaweed supplements (5.8\%), drinks (3.8\%) and jelly/lollies (2.9\%) are rarely consumed. There were no significant differences across gender or age in terms of consumption of the different seaweed products.

INSERT Table 3: Seaweed products consumed.

Respondents indicated that they were most willing to consume sushi wrapped in seaweed (62\%), followed by seaweed flavoured crackers (60\%), seaweed flavoured snacks (54\%), and seaweed soup (52\%) (Appendix 1). Less than half of the respondents were willing to consume seaweed flakes or sprinkles (47\%) or fresh seaweed in a salad (47\%). About onethird (33\%) indicated that they were willing to consume a seaweed supplement, while about one-quarter would be willing to consume seaweed as a drink $(28 \%)$ or in a jelly or sweet $(25 \%)$.

\section{Eating and dietary preferences}

Respondents were also asked about the foods they eat (Table 4). Respondents who had eaten or tasted seaweed in the past were more likely to eat healthier foods such as vegetables, salads, fish/seafood, lentils, pulses, quinoa and couscous. Likewise, increased frequency of consumption of seaweed in the past 12 months was associated with these healthier food choices, as was likelihood to consume seaweed in the next 12 months. Moreover, respondents 
who eat chicken were more likely to agree that they would be likely to eat seaweed in the next 12 months.

INSERT Table 4: Dietary choices and seaweed consumption.

The majority of respondents $(58 \%)$ in this study indicated that they eat a varied diet comprising red meat, fish/seafood, eggs and dairy. Another $23 \%$ indicated that they prefer red meat, pork and chicken to fish or seafood, while $11 \%$ prefer fish and seafood to other meats. Only $5 \%$ reported being vegetarian, while $2 \%$ reported being vegan or pescatarian respectively.

There were significant differences in seaweed consumption across the dietary preference groups (Table 5). In particular, people who prefer to eat red meat, pork or chicken rather than fish or seafood were significantly less likely to have ever eaten seaweed $\left(\chi^{2}=9.56, p=.02\right)$, to have consumed seaweed in the past 12 months $\left(\chi^{2}=16.59, p=.01\right)$ or to consume seaweed in the next 12 months $\left(\chi^{2}=29.28, \mathrm{p}=.00\right)$. People who identified as being either vegetarian, vegan or pescatarian also indicated lower likelihood of consuming seaweed in the next 12 months.

INSERT Table 5: Dietary preferences and seaweed consumption. 


\section{Psychological influences on seaweed consumption}

Exploratory factor analysis revealed five factors (Eigenvalues greater than 1): neophobia $($ alpha $=.85) ;$ responsibility with food and food safety $($ alpha $=.88) ;$ symbolic value (alpha $=$ $.87)$; health consciousness (alpha $=.85)$ and snacking behaviour (alpha $=.85)$ (see Appendix 2 for details). People with higher levels of neophobia were less likely to have eaten seaweed in the past, had consumed seaweed less frequently in the past 12 months and were less likely to consume seaweed in the next 12 months (Table 6). People who are more mindful of their food consumption (reflected by the factor - responsibility with food and food safety) were more likely to have eaten seaweed in the past, had consumed seaweed more frequently in the past 12 months and were more likely to consume seaweed in the next 12 months. Seaweed consumption was more frequent and likely for those who assign symbolic value to food and for those who are more health-conscious. While snacking behaviour did not influence having eaten or tasted seaweed, people with a higher propensity to snack had consumed seaweed more frequently in the past 12 months and are more likely to consume seaweed in the next 12 months.

INSERT Table 6: Psychological influences on seaweed consumption.

\section{Reasons for eating or not eating seaweed}

The sparse literature on seaweed consumption revealed that drivers of seaweed consumption are primarily associated with health, nutrition and environmental benefits, as well as taste (Bouga \& Combet, 2015; Chapman et al., 2015; de Boer et al., 2013; Prager, 2017). Barriers to seaweed consumption are mostly linked to lack of familiarity and neophobia (Chapman et al., 2015; Prager, 2017). 
Based on the literature and media articles about benefits and risks of seaweed consumption, respondents were asked to indicate on a five point Likert-type scale about the relevance of a range of reasons for eating (Table 7) or not eating seaweed (Table 8). The most relevant reasons for eating seaweed are linked to functional benefits including being healthy (64\%), nutritious (61\%), and a natural source of Omega $3(59 \%)$. This finding supports the literature and reflects the consumption of sushi, for example, by Western consumers for health benefits (Altintzoglou et al., 2016). Hedonic reasons such as being tasty (60\%), liking seaweed (59\%) and considering seaweed to be pleasant (53\%) are also relevant reasons for eating seaweed. Other relevant functional reasons include seaweed being fresh (57\%), safe to eat (57\%), a good source of protein $(54 \%)$, low in calories $(52 \%)$, and a good source of iodine $(52 \%)$; diet variety (51\%); and versatility (51\%). More than half of the respondents noted that being environmentally friendly (53\%) and sustainable (52\%) were also relevant reasons for eating seaweed. Respondents likely to eat seaweed in the next 12 months, scored significantly higher $(\mathrm{p}<.001)$ on all the relevant reasons for eating seaweed (Table 7) as compared to the respondents who were unlikely to eat seaweed in the next 12 months.

INSERT Table 7: Relevant reasons (drivers) for eating seaweed. Mean scores and standard deviations presented.

In terms of reasons for not eating seaweed (Table 8), the key issues were the lack of knowledge of the product category, including how to prepare it (45\%), not having recipes (41\%), how long it can be kept (41\%), what to serve it with (38\%), how to store it $(38 \%)$ or where to buy seaweed (36\%). More than one-third of the respondents $(37 \%)$ considered seaweed to be expensive. In terms of sensory characteristics, $39 \%$ indicated that smell would be a relevant reason for not eating seaweed, while dislike of the taste $(37 \%)$, not liking 
seaweed (34\%), dislike of the texture (33\%), being unpleasant (33\%), disliking the appearance of seaweed (29\%), or that it is "weird" $(25 \%)$ are relevant reasons for not eating seaweed. About one-third of the respondents indicated concern about chemical (37\%) or bacterial (36\%) contamination, and whether it would be safe to eat (32\%) as reasons for not consuming seaweed. About one-quarter of respondents reported concern about seaweed not being good for their health $(25 \%)$ or being allergic to it $(23 \%)$ as a reason for not eating seaweed. When comparing the mean scores on the reasons not to eat seaweed (Table 8) between respondents likely and unlikely to eat seaweed in the next 12 months, respondents likely to eat seaweed, scored significantly lower $(\mathrm{p}<.05)$ on all reasons, except for not knowing where to buy seaweed and that seaweed is expensive. This indicates that seaweed is generally perceived to be an expensive, specialty product.

INSERT Table 8: Relevant reasons (barriers) for not eating seaweed. Mean scores and standard deviations presented.

\section{Discussion and implications}

\section{Discussion}

The purpose of this study was to investigate current seaweed consumption and preferences, and to understand consumers' attitudes toward seaweed, including key drivers and barriers of seaweed consumption and psychological factors influencing seaweed consumption in Australia. This understanding will allow the emerging seaweed industry in Australia to adopt a demand-driven approach to developing relevant product offerings and targeted branding strategies. 
The majority of Australian consumers have eaten seaweed, with just over one-third of respondents $(37 \%)$ consuming seaweed at least once per month. However, an analysis of seaweed products consumed indicates that consumption is primarily linked to seaweed as an ingredient in sushi and flavouring in seaweed crackers, meaning that consumption levels in terms of volume (i.e. actual weight) may be relatively low, as a single sushi wrapper weighs about two grams and minimal quantities are incorporated into crackers. Hence, current product formats are potentially not delivering health and nutritional benefits promised from inclusion of seaweed in the diet. Moreover, about one-quarter of Australian consumers have never (knowingly at least) eaten seaweed. Just less than two-thirds of Australian consumers $(62 \%)$ report that it is likely they will consume seaweed in the next 12 months, indicating that Australian consumers are moderately receptive to seaweed products, in particular in the form of more convenient products such as sushi, crackers and snacks.

Our findings indicate that younger consumers, people with higher household incomes and those with higher levels of education are more likely to consume seaweed. Moreover, females report higher levels of consumption in the past 12 months. Thus, the well-educated, younger (under 35 years of age) female is the primary target market for seaweed products. Developing convenient and sophisticated seaweed products with tailored branding that would appeal to this demographic will be critical to the emerging Australian seaweed industry and potentially that of other Western societies.

In keeping with the literature (Prager, 2017), health and nutritional benefits were identified as the most relevant reason for consuming seaweed. More health-conscious consumers are a primary market for seaweed meaning that new product development and marketing claims need to be grounded in evidence and emphasise the significant health and nutritional benefits that can be derived from seaweed consumption. We note the need to address the knowledge gap of how much seaweed and which species must be used to deliver the desired benefits. 
Furthermore, the environmental and sustainability benefits of seaweed are considered relevant reasons for eating seaweed. This has been addressed in Australia and elsewhere in demonstrating the benefits of integrating seaweed with other seafood production to minimise environmental impacts (Lawton, Mata, de Nys, \& Paul, 2013).

Our findings indicated that people who are more mindful in their food choices and the environmental impacts of food, as well as food safety issues, are more likely to eat seaweed. Hence, marketing claims and branding strategies need to reflect this desire for more sustainable and safer food, and this should cover the whole supply chain of harvesting, production and processing of seaweed products. While quite rare, there have been instances where seaweed products have been recalled because of high levels of particular elements (such as arsenic and iodine) (Canadian Food Inspection Agency, 2012; Food Standards Australia New Zealand, 2011a, 2011b, 2018; Wong, 2010). However, there are two important elements to food safety: the first is that it has been a conservative approach by food agencies where the data (i.e. the variation in the elements) is not well understood, in particular, the actual bioavailability to human consumers; the second is educational as all seaweed contains different elements but only one or two species may do so to a problematic level. There are roles for more regular and nuanced testing to be done as with any new industry scale up, and also for aquaculture rather than wild-harvest as this will provide greater control of the seasonal and environmental conditions of the product. That aside, Australian consumers do not appear to be too concerned about the safety of seaweed or the potential for bacterial or chemical contamination. Nevertheless, safety and quality procedures and regulations, such as those developed in France (CEVA, 2014), will be required to remove potential risks of consumption.

Consumers of seaweed are more likely to be adventurous with food and willing to try new products (Altintzoglou et al., 2016). This finding is in keeping with a study in Norway, which 
revealed that younger consumers who are highly innovative with their food preparation are more likely to consume a novel food product, such as sushi (Altintzoglou et al., 2016). Providing opportunities for sampling the product and development of innovative seaweed products will appeal to these neophilic consumers. Moreover, facilitating trial and experimentation by ensuring seaweed products are featured on menus, cooking shows, cooking websites and recipe books will encourage consumption by these more adventurous food consumers (e.g. Jamie Oliver, Iron Chef and Nigella Lawson have all featured seaweed). Conversely, neophobia has been identified as a major obstacle for consuming seaweed. Managing the sensory characteristics of seaweed during product development including smell, appearance and texture will be critical to wider market acceptance. Avoiding aversion or disgust by including seaweed as a minor ingredient in other more familiar products may overcome this barrier, however this brings with it the problematic mismatch between perceived health drivers and ensuring sufficient consumption. Identifying more palatable seaweed products will lead to consumer acceptance (Chapman et al., 2015).

Seaweed consumers are also more likely to assign symbolic value to food choices. Therefore, capitalising on the associations of "you are what you eat" and the potential for seaweed to be considered a "chic" or "trendy" food choice should drive branding strategies and promotional appeals for new seaweed products. Finally, seaweed consumption is linked to a propensity to snack, representing an opportunity for the seaweed industry to develop healthy, tasty and convenient seaweed snacks that would appeal to key target markets. In this respect, snacking may be the most transparent product development strategy, as it is unlikely that 'snackers' believe that they are going to gain direct health benefits, instead gaining indirect benefits by substituting out "unhealthy" options. 
Percentage agreement with potential reasons for not consuming seaweed was generally lower than agreement with reasons for consuming seaweed, indicating Australian consumers perceive seaweed consumption to be more associated with drivers or benefits than potential barriers. The most critical barriers to seaweed consumption are lack of familiarity with and lack of knowledge of the product category. Hence, utilising packaging, labelling, point of purchase, and other marketing communication strategies (e.g. social media) to educate consumers on where to buy the product, how to store it, how to prepare and serve it, and providing appealing recipes are critical to increasing seaweed consumption. This will be complicated as there are many different types of seaweeds (e.g. brown, red and green taxonomic groups) and they all have different tastes, texture, appearances and biochemical compositions. There is a risk that one seaweed species or product may deter consumers from tasting others, so some care needs to be taken in differentiating between seaweeds in the marketplace. This may be best be achieved through domestic production to complement the increase in domestic processing of seaweed products using imported ingredients.

Other barriers to seaweed consumption include lack of availability and affordability. Hence, overcoming these perceptions will rely upon developing affordable seaweed foods that represent value for money in order to move beyond the present niche markets into wider distribution in mainstream food outlets.

\section{Academic and managerial implications}

To the best of our knowledge, this is the first time that consumers' current consumption of seaweed and the perceived drivers and barriers to seaweed consumption have been measured and linked to the influence of key psychological variables. A model of seaweed consumption is proposed, including key drivers (e.g. health, nutrition and taste) and barriers (e.g. 
knowledge of how to use, prepare and store, and cost), along with moderating variables based on demographic differences and mediating variables based on relevant psychological influences, such as neophobia, health-consciousness, symbolic value, responsibility with food and food safety, and snacking behaviour. This conceptual model will provide a framework for further studies of seaweed consumption. In particular, it has strengthened understanding of influences on consumption of novel and unfamiliar foods within the context of seaweed.

This research provides valuable insights into consumer preferences for a diverse range of seaweed products. The findings have uncovered key barriers and drivers for expanding seaweed consumption, allowing prioritisation of research agendas including new product development, as well as marketing and branding efforts. A profile of the most important seaweed consumer (i.e. female, under 35, highly educated) has been developed and will allow for more targeted product development and branding strategies. A business case for the potential for seaweed to become a new industry in Australia can be developed based on this information and tailored to different business types.

\section{Limitations of the research and areas of future research}

This study is confined to an online national survey of 521 Australian consumers. While representative of Western societies in general, future research involving larger samples and in other Western societies across the globe will strengthen understanding. Future studies may utilise other methodologies such as projective techniques to elicit top of mind associations or focus groups to test new product/packaging concepts and associated marketing and branding strategies including the use of marketing claims based on the benefits of seaweed consumption. These qualitative techniques are valuable for gaining rich insights, in particular around emotional responses to and acceptance of novel food. 


\section{References}

Aiking, H. (2011). Future protein supply. Trends in Food Science and Technology, 22(2-3), 112-120.

Altintzoglou, T., Heide, M., Wien, A. H., \& Honkanen, P. (2016). Traditional sushi for modern consumers: a comparison between sushi consumption behavior in Japan and Norway. Journal of Food Products Marketing, 27(6), 717-732.

Angell, A. R., Angell, S. F., de Nys, R., \& Paul, N. A. (2016). Seaweed as a protein source for mono-gastric livestock. Trends in Food Science and Technology, 54, 74-84.

Angell, A. R., Mata, L., de Nys, R., \& Paul, N.A. (2016). The protein content of seaweeds: a universal nitrogen-to-protein conversion factor of five. Journal of Applied Phycology, 28(1), 511-524.

Arioli, T., Mattner, S. W., \& Winberg, P.C. (2015). Applications of seaweed extracts in Australian agriculture: past, present and future. Journal of Applied Phycology, 27(5), 20072015.

Arvola, A., Lähteenmäki, L., \& Tuorila, H. (1999). Predicting the intent to purchase unfamiliar and familiar cheeses: the effects of attitudes, expected liking and food neophobia. Appetite, 32(1), 113-126.

Barrena, R., \& Sánchez, M. (2012). Neophobia, personal consumer values and novel food acceptance. Food Quality and Preference, 27, 72-84.

Beardsworth, A., Bryman, A., Keil, T., Goode, J., Haslam, C., \& Lancashire, E. I. (2002). Women, men, and food. The significance of gender for nutritional attitudes and choices. British Journal of Food, 104, 470-491. 
Birch, D., Brunsø, K., Grunert, K., \& Memery, J. (2017). Modular food-related lifestyle: a new instrument for consumer segmentation in food marketing. Paper presented at the International Food Marketing Research Symposium, 15-16 June, Dubrovnik, Croatia.

Borgogno, M., Favotto, S., Corazzin, M., Cardello, A., \& Piasentier, E. (2015). The role of product familiarity and consumer involvement on liking and perceptions of fresh meat. Food Quality and Preference, 44, 139-147.

Bouga, M., \& Combet, E. (2015). Emergence of seaweed and seaweed-containing foods in the UK: focus on labeling, iodine content, toxicity and nutrition. Foods, 4(2), 240-253.

Brownlee, I., Fairclough, A., Hall, A., \& Paxman, J. (2012). The potential health benefits of seaweed and seaweed extract. In V. H. Pomin (Ed.), Seaweed: ecology, nutrient composition and medicinal uses. Marine Biology: Earth Sciences in the 21st Century (pp. 119-136). New York, NY: Nova Science Publishers.

Brunsø, K., \& Grunert, K. G. (1995). Development and testing of a crossculturally valid instrument: food-related life style. Advances in Consumer Research, 22, 475-480.

Brunsø, K., Verbeke, W., Olsen, S.O., \& Jeppesen, L. F. (2009). Motives, barriers and quality evaluation in fish consumption situations: exploring and comparing heavy and light users in Spain and Belgium. British Food Journal, 111, 699-716.

Canadian Food Inspection Agency (2012). Inorganic arsenic and hijiki seaweed consumption. Retrieved from http://www.inspection.gc.ca/food/information-for-consumers/fact-sheets-andinfographics/products-and-risks/chemical-hazards/inorganicarsenic/eng/1332268146718/1332268231124. 
CEVA (2014). Edible seaweed and French regulation - Synthesis made by CEVA (31/03/2014). Retrieved from https://www.cybercolloids.net/sites/default/files/seaweed\%20and\%20regulation2014.pdf.

Chapman, A., Stevant, P., \& Larssen, W. (2015). Food or fad? Challenges and opportunities for including seaweeds in a Nordic diet. Botannica Marina, 58(6), 423-433.

de Boer, J., Schösler, H., \& Boersema, J. (2013). Motivational differences in food orientation and the choice of snacks made from lentils, locusts, seaweed or "hybrid" meat. Food Quality and Preference, 28(1), 32-35.

Duarte, C., Wu, J., Xiao, X., Bruhn, A., \& Krause-Jensen, D. (2017). Can seaweed farming play a role in climate change mitigation and adaptation? Frontiers in Marine Science, 4, Article 100.

Elliot, C. (2014). Food as people: teenagers' perspectives on food personalities and implications for healthy eating. Social Science and Medicine, 121, 85-90.

Fagerli, R. A., \& Wandel, M. (1999). Gender differences in opinions and practices with regard to a "healthy diet". Appetite, 32(2), 171-190.

Fernández-Martín F., López-López I., Cofrades, S., \& Colmenero, F. J. (2009). Influence of adding Sea Spaghetti seaweed and replacing the animal fat with olive oil or a konjac gel on pork meat batter gelation. Potential protein/alginate association. Meat Science, 83(2), 209217.

Fleurence, J., Morancais, M., Dumay, J., Decottignies, P., Turpin, V., Munier, M., Jaouen, P. (2012). What are the prospects for using seaweed in human nutrition and for marine animals raised through aquaculture? Trends in Food Science and Technology, 27, 57-61. 
Flight, I., Leppard, P., \& Cox, D. N. (2003). Food neophobia and associations with cultural diversity and socio-economic status amongst rural and urban Australian adolescents.

Appetite, 41, 51-59.

Food Standards Australia New Zealand (2011a). Wang Dried Seaweed - other (high levels of naturally occurring iodine) - 28 June 2011. Retrieved from http://www.foodstandards.gov.au/industry/foodrecalls/recalls/Pages/wangdriedseaweedothe5 203.aspx.

Food Standards Australia New Zealand (2011b). Dried Seaweed - other (high levels of naturally occurring iodine) 8 November 2011. Retrieved from http://www.foodstandards.gov.au/industry/foodrecalls/recalls/Pages/driedseaweedotherhig53 39.aspx.

Food Standards Australia New Zealand (2013). Monitoring of inorganic arsenic and iodine in seaweed. Retrieved from

http://www.foodstandards.gov.au/consumer/safety/arseniciodine/Pages/default.aspx.

Food Standards Australia New Zealand (2016). Imported food risk statement: hijiki seaweed and inorganic arsenic. Retrieved from

https://www.foodstandards.gov.au/consumer/importedfoods/Documents/Hijiki\%20seaweed\% 20and\%20inorganic\%20arsenic.pdf.

Food Standards Australia New Zealand (2018). The Whole Foodies Sea Vegetables Mixed Seaweed. Retrieved from http://www.foodstandards.gov.au/industry/foodrecalls/recalls/Pages/The-Whole-FoodiesSEA-VEGETABLES-Mixed-Seaweed.aspx. 
Global Industry Analysts (2015). The global snack foods market. Retrieved from http://www.strategyr.com/MarketResearch/Snack_Foods_Salted_Baked_Frozen_Snacks_Mar ket_Trends.asp.

Gould, S. J. (1988). Consumer attitudes toward health and health care: a differential perspective. Journal of Consumer Affairs, 22(1), 96-118.

Gould, S. J. (1990). Health consciousness and health behavior: the application of a new health consciousness scale. American Journal of Preventive Medicine, 6(4), 228-237.

Gresham, G., Hafer, J., \& Markowski, E. (2006). Inter-functional market orientation between marketing departments and technical departments in the management of the new product development process. Journal of Behavioral and Applied Management, 8(1), 53-65.

Gupta, S., \& Abu-Ghannam, N. (2011). Bioactive potential and possible health effects of edible brown seaweeds. Trends in Food Science and Technology, 22, 315-326.

Hall, A. C., Fairclough, A. C., Mahadevan, K., \& Paxman, J. R. (2012). Ascophyllum nodosum enriched bread reduces subsequent energy intake with no effect on post-prandial glucose and cholesterol in healthy, overweight males. A pilot study. Appetite, 58(1), 379-386.

Haynes-Maslow, L., Parsons, S. E., Wheeler, S. B., \& Leone, L. A. (2013). A qualitative study of perceived barriers to fruit and vegetable consumption among low-income populations, North Carolina, 2011. Preventing Chronic Disease, 10, Article 120206.

Jain, K., \& Srinivasan, N. (1990). An empirical assessment of multiple operationalizations of involvement. In M. E. Goldberg, G. Gorn \& R. W. Pollay (Eds.), Advances in Consumer Research 17 (pp. 594-602). Provo, UT: Association for Consumer Research. 
Jiménez-Colmenero, F., Cofrades, S., López-López, I., Ruiz-Capillas, C., Pintado, T., \& Solas, M. T. (2010). Technological and sensory characteristics of reduced/low-fat, low-salt frankfurters as affected by the addition of konjac and seaweed. Meat Science, 84(3), 356-363.

Juhl, H., \& Poulsen C. (2000). Antecedents and effects of consumer involvement in fish as a product group. Appetite, 34, 261-267.

Köster, E. P. (2009). Diversity in the determinants of food choice: A psychological perspective. Food Quality and Preference, 20, 70-82.

Kubberød, E., Ueland, Ø., Rødbotten, M., Westad, F., \& Risvik, E. (2002). Gender specific preferences and attitudes towards meat. Food Quality and Preference, 13, 285-294.

Laurent, G., \& Kapferer, J.- N. (1985). Measuring consumer involvement profiles. Journal of Marketing Research, 22, 41-53.

Lawton, R. J., Mata, L., de Nys, R., \& Paul, N. A. (2013). Algal bioremediation of waste waters from land-based aquaculture using ulva: selecting target species and strains. PLoS ONE, 8(10), Article e77344.

Loewen, R., \& Pliner, P. (2000). The food situations questionnaire: a measure of children's willingness to try novel foods in stimulating and non-stimulating situations. Appetite, 35, 239-250.

Matthews, L. (2018). Should we eat more seaweed? Friday Night Feast. Retrieved from https://www.jamieoliver.com/news-and-features/features/should-we-eat-more-seaweed/.

Meiselman, H. L., Mastroianni, G., Buller, M., \& Edwards, J. (1999). Longitudinal measurement of three eating behavior scales during a period of change. Food Quality and Preference, 10, 1-8. 
Mintel (2016). Seaweed-flavoured food and drink launches increased by $147 \%$ in Europe between 2011 and 2015. Mintel Press Office. Retrieved from http://www.mintel.com/presscentre/food-and-drink/seaweed-flavoured-food-and-drink-launches-increased-by-147-ineurope-between-2011-and-2015.

Moreau, C. P., Lehamann, D. R., \& Markman, A.B. (2001). Entrenched knowledge structures and consumer response to new products. Journal of Marketing Research, 38(1), 14-29.

Mouritsen, O. G., Johansen, M., \& Mouritsen, J. D. (2013). Seaweed: edible, available and sustainable. Chicago, IL: University of Chicago Press.

Nordin, S., Broman, D. A., Garvill, J., \& Nyroos, M. (2004). Gender differences in factors affecting rejection of food in healthy young Swedish adults. Appetite, 43(3), 295-301.

Papista, E., \& Krystallis, A. (2013). Investigating the types of value and cost of green brands: proposition of a conceptual framework. Journal of Business Ethics, 115(1), 75-92.

Perrea, T., Krystallis, A., Engelgreen, C., \& Chrysochou, P. (2017). Much too new to eat it? Customer value and its impact on consumer-product relationship in the context of novel food products. Journal of Product and Brand Management, 26(6), 616-630.

Pieniak, Z., Verbeke, W., Scholderer, J., Brunsø, K., \& Olsen, S. O. (2008). Impact of consumers' health beliefs, health involvement and risk perception on fish consumption. British Food Journal, 110(9), 898-915.

Pliner, P., \& Hobden, K. (1992). Development of a scale to measure the trait of food neophobia in humans. Appetite, 19(2), 105-120.

Potter, R., Stojceska, V., \& Plunkett, A. (2013). The use of fruit powders in extruded snacks suitable for children's diets. LWT - Food Science and Technology, 51(2), 537-544. 
Prager, H. (2017). What can be done to increase acceptance of seaweed into the western diet? Retrieved from https://www.ntnu.edu/documents/139799/1273574286/TPD4505.Henry.Prager.pdf/bcb465ea $-79 \mathrm{e} 3-45 \mathrm{c} 0-\mathrm{b} 1 \mathrm{~d} 2-1775 \mathrm{~b} 3 \mathrm{~d} 1852 \mathrm{f}$.

Rathod, R., \& Annapure, S. (2016). Effect of extrusion process on antinutritional factors and protein and starch digestibility of lentil splits. LWT - Food Science and Technology, 66, 114123.

Raudenbush, B., \& Frank, R. A. (1999). Assessing food neophobia: the role of stimulus familiarity. Appetite, 32, 261-271.

Roohinejad, S., Koubaa, M., Barba F., Saljoughian, S., Amid, M., \& Greiner, R. (2017). Application of seaweeds to develop new food products with enhanced shelf-life, quality and health-related beneficial properties. Food Research International, 99, 1066-1083.

Schösler, H., de Boer, J., \& Boersema, J. J. (2012). Can we cut out the meat of the dish? Constructing consumer-oriented pathways towards meat substitution. Appetite, 58(1), 39-47.

Tan, H. S. G., Fischer, A. R., van Trijp, H. C., \& Stieger, M. (2016). Tasty but nasty? Exploring the role of sensory-liking and food appropriateness in the willingness to eat unusual novel foods like insects. Food Quality and Preference, 48, 293-302.

Tinellis, C. (2014). Coastal chef: culinary art of seaweed and algae in the 21st century, Ulladulla, NSW, Australia: Harbour Publishing House.

Trondsen, T., Scholderer, J., Lund, E., \& Eggen, A. E. (2003). Perceived barriers to consumption of fish among Norwegian women. Appetite, 41(3), 301-314. 
Tuorila, H., Lähteenmäki, L., Pohjalainen, L., \& Lotti, L. (2001). Food neophobia among the Finns and related responses to familiar and unfamiliar foods. Food Quality and Preference, $12,29-37$.

Tuorila, H., Meiselman, H. L., Bell, R., Cardello, A. V., \& Johnson, W. (1994). Role of sensory and cognitive information in the enhancement of certainty and liking for novel and familiar foods. Appetite, 23(3), 231-246.

van der Spiegel, M., Noordam M. Y., \& van Der Fels-Klerx, H. J. (2013). Safety of novel protein sources (insects, microalgae, seaweed, duckweed, and rapeseed) and legislative aspects for their application in food and feed production. Comprehensive Reviews in Food Science and Food Safety, 12(6), 662-678.

Verbeke, W. (2005). Consumer acceptance of functional foods: socio-demographic, cognitive and attitudinal determinants. Food Quality and Preference, 16(1), 45-57.

Verbeke, W. (2015). Profiling consumers who are ready to adopt insects as a meat substitute in a Western society. Food Quality and Preference, 39, 147-155.

Verbeke, W., Sans, P., \& van Loo, E. J. (2015). Challenges and prospects for consumer acceptance of cultured meat. Journal of Integrative Agriculture, 14(2), 285-294.

Verbeke, W., Scholderer, J., \& Lähteenmäki, L. (2009). Consumer appeal of nutrition and health claims in three existing product concepts. Appetite, 52(3), 684-692.

Warwicker, M., \& Taylor, A. L. (2012). Seaweed: should people eat more of it? BBC News. Retrieved from http://www.bbc.com/news/magazine-17870743. 
Wong, J. (2010). Food recall: dried seaweed with unusually high levels of iodine. Australian Food News. Retrieved from http://www.ausfoodnews.com.au/2010/03/17/food-recall-driedseaweed-with-unusually-high-levels-of-iodine.html. 


\title{
APPENDIX 1: Willingness to eat seaweed products
}

INSERT Appendix 1 Table

\begin{abstract}
APPENDIX 2: Psychological influences on seaweed consumption - measurement scales and factor loadings
\end{abstract}

INSERT Appendix 2 Table 


\section{Who eats seaweed? A Australian perspective}

\section{List of tables included in this document:}

Table 1: Respondent profile.

Table 2: Demographic differences associated with seaweed consumption.

Table 3: Seaweed products consumed.

Table 4: Dietary choices and seaweed consumption.

Table 5: Dietary preferences and seaweed consumption.

Table 6: Psychological influences on seaweed consumption.

Table 7: Relevant reasons (drivers) for eating seaweed. Mean scores and standard deviations presented.

Table 8: Relevant reasons (barriers) for not eating seaweed. Mean scores and standard deviations presented.

APPENDIX 1: Willingness to eat seaweed products

APPENDIX 2: Psychological influences on seaweed consumption - measurement scales and factor loadings 
Table 1: Respondent profile.

\begin{tabular}{lcc}
\hline Demographics & \multicolumn{2}{c}{ Total } \\
\cline { 2 - 3 } Gender & 202 & 38.8 \\
Male & 315 & 60.5 \\
Female & 4 & 0.8 \\
Prefer not to say & & \\
\hline Highest educational level attained & 2 & 0.4 \\
Primary school & 157 & 30.1 \\
Secondary school & 171 & 32.8 \\
Trade or technical certificate & 126 & 24.2 \\
Undergraduate degree & 65 & 12.5 \\
Postgraduate degree & & \\
\hline Annual HOUSEHOLD income after tax (AUD) & 166 & 31.9 \\
Under AUD40,000 & 84 & 16.1 \\
AUD40,000 - 59,999 & 133 & 25.5 \\
AUD60,000 - 99,999 & 138 & 26.5 \\
AUD100,000 or over & & \\
\hline Age category (years) & & \\
$18-35$ & & \\
$35-44$ & 177 & 34.4 \\
45 - 59 & 100 & 19.5 \\
$60+$ & 135 & 26.3 \\
\hline
\end{tabular}


Table 2: Demographic differences associated with seaweed consumption.

\begin{tabular}{|c|c|c|c|}
\hline Demographics & $\begin{array}{l}\text { Ever eaten } \\
\text { seaweed }\end{array}$ & $\begin{array}{l}\text { Eaten >once a month } \\
\text { in the past } 12 \text { months }\end{array}$ & $\begin{array}{l}\text { Likely to eat in the } \\
\text { next } 12 \text { months }\end{array}$ \\
\hline Sample & $\begin{array}{c}74 \% \\
(n=370)\end{array}$ & $\begin{array}{c}37 \% \\
(n=195)\end{array}$ & $\begin{array}{c}62 \% \\
(n=272)\end{array}$ \\
\hline \multicolumn{4}{|l|}{ Gender } \\
\hline Males & $70 \%$ & $32 \%$ & $63 \%$ \\
\hline \multirow[t]{2}{*}{ Females } & $76 \%$ & $41 \%$ & $61 \%$ \\
\hline & $\chi^{2}=2.55(\mathrm{p}=.11)$ & $\chi^{2}=4.52(p=.03)$ & $\chi^{2}=.175(\mathrm{p}=.68)$ \\
\hline \multicolumn{4}{|l|}{ Purchasing role } \\
\hline Main shopper & $76 \%$ & $38 \%$ & $64 \%$ \\
\hline \multirow[t]{2}{*}{ Joint shopper } & $66 \%$ & $34 \%$ & $55 \%$ \\
\hline & $\chi^{2}=4.08(p=.04)$ & $\chi^{2}=0.61(p=.43)$ & $\chi^{2}=2.26(p=.13)$ \\
\hline \multicolumn{4}{|l|}{ Education } \\
\hline Secondary & $65 \%$ & $25 \%$ & $52 \%$ \\
\hline Trade/tech & $75 \%$ & $35 \%$ & $46 \%$ \\
\hline Undergraduate & $78 \%$ & $46 \%$ & $57 \%$ \\
\hline \multirow[t]{2}{*}{ Postgraduate } & $83 \%$ & $57 \%$ & $82 \%$ \\
\hline & $\chi^{2}=9.84(p=.02)$ & $\chi^{2}=25.57(p=.00)$ & $\chi^{2}=21.90(p=.00)$ \\
\hline \multicolumn{4}{|l|}{$\begin{array}{l}\text { Household } \\
\text { income }\end{array}$} \\
\hline AUD $<40 k$ & $64 \%$ & $30 \%$ & $55 \%$ \\
\hline AUD $40 \mathrm{k}-60 \mathrm{k}$ & $68 \%$ & $30 \%$ & $55 \%$ \\
\hline AUD $60 \mathrm{k}-100 \mathrm{k}$ & $76 \%$ & $38 \%$ & $64 \%$ \\
\hline \multirow[t]{2}{*}{ AUD $>100 k$} & $86 \%$ & $51 \%$ & $72 \%$ \\
\hline & $\chi^{2}=19.07(p=.00)$ & $\chi^{2}=17.01(p=.00)$ & $\chi^{2}=9.24(\mathrm{p}=.03)$ \\
\hline \multicolumn{4}{|l|}{ Age (years) } \\
\hline$<35$ & $82 \%$ & $49 \%$ & $65 \%$ \\
\hline $35-44$ & $73 \%$ & $35 \%$ & $62 \%$ \\
\hline $45-59$ & $72 \%$ & $36 \%$ & $62 \%$ \\
\hline \multirow[t]{2}{*}{+60} & $63 \%$ & $23 \%$ & $56 \%$ \\
\hline & $\chi^{2}=12.09(p=.01)$ & $\chi^{2}=20.62(p=.00)$ & $\chi^{2}=1.76(p=.62)$ \\
\hline
\end{tabular}


Table 3: Seaweed products consumed.

\begin{tabular}{lcc}
\hline Seaweed product & \multicolumn{2}{c}{ Total } \\
\cline { 2 - 3 } & $n$ & $\%$ \\
\hline Sushi rolls wrapped in seaweed & 368 & 70.6 \\
Seaweed flavoured crackers & 253 & 48.6 \\
Seaweed in a soup (e.g. Miso) & 184 & 35.3 \\
Seaweed flavoured snacks & 118 & 22.6 \\
Fresh seaweed in a salad & 98 & 18.8 \\
Seaweed flakes or sprinkles & 71 & 13.6 \\
Seaweed supplement & 30 & 5.8 \\
Seaweed in a drink (e.g. tea, smoothie) & 20 & 3.8 \\
Seaweed jelly or lollies & 15 & 2.9 \\
I have not eaten any of these & 105 & 20.2 \\
\hline
\end{tabular}

Table 4: Dietary choices and seaweed consumption.

\begin{tabular}{lcc|cc|cc}
\hline I eat.... & \multicolumn{2}{c|}{ Eaten: } & \multicolumn{2}{c|}{ Frequency: } & \multicolumn{2}{c}{ Intention: } \\
\cline { 2 - 7 } & No & Yes & $\begin{array}{c}<\text { once } a \\
\text { month }\end{array}$ & $\begin{array}{c}\text { >once } a \\
\text { month }\end{array}$ & Unlikely & Likely \\
\hline red meat: & 4.7 & $4.8^{\mathrm{ns}}$ & 4.8 & $4.8^{\mathrm{ns}}$ & 4.7 & $4.8^{\mathrm{ns}}$ \\
lollies, cake, desserts, chocolate: & 4.5 & $4.6^{\mathrm{ns}}$ & 4.5 & $4.6^{\mathrm{ns}}$ & 4.5 & $4.7^{\mathrm{ns}}$ \\
or drink dairy products: & 5.4 & $5.7^{\mathrm{ns}}$ & 5.6 & $5.6^{\mathrm{ns}}$ & 5.5 & $5.6^{\mathrm{ns}}$ \\
chicken: & 4.8 & $5.0^{\mathrm{ns}}$ & 4.9 & $4.9^{\mathrm{ns}}$ & 4.7 & $5.1^{* *}$ \\
fish and seafood: & 3.8 & $4.3^{* *}$ & 3.9 & $4.6^{* * *}$ & 3.6 & $4.6^{* * *}$ \\
vegetables: & 5.5 & $6.0^{* * *}$ & 5.8 & $6.1^{* *}$ & 5.6 & $6.1^{* * *}$ \\
salads: & 4.7 & $5.2^{* * *}$ & 4.9 & $5.3^{* *}$ & 4.9 & $5.4^{* * *}$ \\
lentils and pulses: & 2.4 & $3.8^{* * *}$ & 2.9 & $3.7^{* * *}$ & 2.7 & $3.5^{* * *}$ \\
quinoa and couscous: & 2.1 & $3.1^{* * *}$ & 2.4 & $3.5^{* * *}$ & 2.4 & $3.2^{* * *}$ \\
\hline
\end{tabular}

ns: no significant; $* * \mathrm{p}<0.01 ; * * * \mathrm{p}<0.001$. 
Table 5: Dietary preferences and seaweed consumption.

\begin{tabular}{lccc}
\hline Dietary preference & Eaten seaweed: & $\begin{array}{c}\text { Eaten >once a } \\
\text { month: }\end{array}$ & Likely to eat: \\
\hline $\begin{array}{l}\text { I prefer to eat fish but I will } \\
\text { eat other animal proteins such } \\
\text { as red meat, pork or chicken }\end{array}$ & $83 \%$ & $44 \%$ & $71 \%$ \\
\hline $\begin{array}{l}\text { I eat red meat, fish/seafood, } \\
\text { eggs and dairy }\end{array}$ & $76 \%$ & $41 \%$ & $70 \%$ \\
\hline $\begin{array}{l}\text { I am vegetarian/ } \\
\text { vegan/pescatarian }\end{array}$ & $73 \%$ & $47 \%$ & $50 \%$ \\
\hline $\begin{array}{l}\text { I prefer to eat red meat, pork } \\
\text { and or chicken rather than fish } \\
\text { or seafood }\end{array}$ & $63 \%$ & $22 \%$ & $42 \%$ \\
\hline & $\chi^{2}=9.56(p=.02)$ & $\chi^{2}=16.59(\mathrm{p}=.01)$ & $\chi^{2}=29.28(\mathrm{p}=.00)$ \\
\hline
\end{tabular}

Table 6: Psychological influences on seaweed consumption.

\begin{tabular}{lcc|cc|cc}
\hline Psychological influence & Ever eaten & \multicolumn{2}{|c|}{$\begin{array}{c}\text { Frequency in past } \\
\text { 12 months }\end{array}$} & \multicolumn{2}{c}{$\begin{array}{c}\text { Intention in next } \\
\text { 12 months }\end{array}$} \\
\cline { 2 - 7 } & No & Yes & $\begin{array}{c}<\text { once a } \\
\text { month }\end{array}$ & $\begin{array}{c}\text { > once } a \\
\text { month }\end{array}$ & Unlikely & Likely \\
\hline Neophobic & 4.1 & $3.3^{* * *}$ & 3.8 & $3.2^{* * *}$ & 4.0 & $3.2^{* * *}$ \\
Responsibility/food safety & 4.6 & $5.0^{* *}$ & 4.8 & $5.1^{* *}$ & 4.5 & $5.1^{* * *}$ \\
Symbolic value & 3.8 & $4.3^{* * *}$ & 4.0 & $4.5^{* * *}$ & 3.7 & $4.5^{* * *}$ \\
Health-consciousness & 4.5 & $4.9^{* *}$ & 4.7 & $5.0^{* *}$ & 4.4 & $5.0^{* * *}$ \\
Snacking behaviour & 3.6 & $3.8^{\text {ns }}$ & 3.6 & $4.0^{* *}$ & 3.5 & $3.9^{* *}$ \\
\hline
\end{tabular}

ns: no significant; $* * \mathrm{p}<0.01 ; * * * \mathrm{p}<0.001$. 
Table 7: Relevant reasons (drivers) for eating seaweed. Mean scores and standard deviations presented.

\begin{tabular}{lccc}
\hline Reasons for eating seaweed & Mean & SD & \% Relevant \\
\hline It is healthy & 3.60 & 1.25 & 64 \\
It is nutritious & 3.52 & 1.26 & 61 \\
It is a natural source of omega 3 & 3.47 & 1.27 & 59 \\
It is tasty & 3.46 & 1.35 & 60 \\
It is natural & 3.45 & 1.24 & 60 \\
I like it & 3.43 & 1.35 & 59 \\
It is safe & 3.41 & 1.26 & 57 \\
It is fresh & 3.40 & 1.23 & 57 \\
It is a source of protein & 3.35 & 1.25 & 54 \\
It is low in calories & 3.31 & 1.29 & 52 \\
It is sustainable & 3.31 & 1.26 & 53 \\
It is environmentally friendly & 3.31 & 1.25 & 53 \\
It is a good source of iodine & 3.30 & 1.24 & 52 \\
It is pleasant & 3.29 & 1.32 & 53 \\
It adds variety to my diet & 3.27 & 1.29 & 51 \\
It is versatile - can be used in different ways & 3.27 & 1.26 & 51 \\
It is good value for money & 3.22 & 1.24 & 48 \\
It is convenient & 3.22 & 1.25 & 47 \\
It is organic & 3.16 & 1.27 & 48 \\
I like the texture & 3.13 & 1.28 & 45 \\
It is a natural source of salt & 3.12 & 1.23 & 43 \\
It would support the seafood industry & 2.99 & 1.23 & 37 \\
It would support the development of new businesses & 2.95 & 1.20 & 35 \\
I like the way it looks & 2.88 & 1.22 & 30 \\
I like the smell & 2.81 & 1.23 & 29 \\
It is a vegetarian option & 2.81 & 1.31 & 33 \\
It is a vegan option & 2.65 & 1.29 & 27 \\
It is novel & 2.63 & 1.24 & 21 \\
\hline
\end{tabular}


Table 8: Relevant reasons (barriers) for not eating seaweed. Mean scores and standard deviations presented.

\begin{tabular}{lccc}
\hline Reasons for not eating seaweed & Mean & SD & \% Relevant \\
\hline I do not know how to prepare it & 3.12 & 1.30 & 45 \\
I do not know of any recipes for it & 3.02 & 1.29 & 41 \\
It is expensive & 3.02 & 1.26 & 37 \\
I do not know how long you can keep it & 3.00 & 1.27 & 41 \\
I do not know what to serve it with & 2.98 & 1.30 & 38 \\
I dislike the smell & 2.95 & 1.31 & 39 \\
I do not know how to store it & 2.93 & 1.26 & 38 \\
I dislike the taste & 2.93 & 1.39 & 37 \\
I do not know where to buy it & 2.93 & 1.28 & 36 \\
I'm concerned about chemical contamination & 2.92 & 1.34 & 37 \\
I'm concerned about bacterial contamination & 2.91 & 1.29 & 36 \\
I do not like it & 2.88 & 1.41 & 34 \\
I dislike the texture & 2.85 & 1.30 & 33 \\
It is unpleasant & 2.82 & 1.36 & 33 \\
I'm concerned about how safe it is to eat & 2.78 & 1.29 & 32 \\
I dislike the way it looks & 2.73 & 1.28 & 29 \\
It is weird & 2.63 & 1.30 & 25 \\
I'm concerned it may not be good for my health & 2.53 & 1.28 & 25 \\
I might be allergic to it & 2.51 & 1.29 & 23 \\
\hline
\end{tabular}




\section{APPENDIX 1: Willingness to eat seaweed products}

\begin{tabular}{lcc}
\hline Seaweed Product & Mean (SD) & \% Willing \\
\hline Sushi rolls wrapped in seaweed & $3.58(1.51)$ & $62.4 \%$ \\
Seaweed flavoured crackers & $3.46(1.39)$ & $59.5 \%$ \\
Seaweed flavoured snacks & $3.31(1.39)$ & $53.7 \%$ \\
Seaweed in a soup (e.g. Miso) & $3.30(1.44)$ & $52.4 \%$ \\
Seaweed flakes or sprinkles & $3.16(1.35)$ & $47.0 \%$ \\
Fresh seaweed in a salad & $3.12(1.38)$ & $47.6 \%$ \\
Seaweed supplement & $2.86(1.27)$ & $33.4 \%$ \\
Seaweed in a drink (e.g. tea, smoothie) & $2.63(1.27)$ & $28.0 \%$ \\
Seaweed jelly or lollies & $2.55(1.25)$ & $25.0 \%$ \\
\hline (Scale: 7 point with 1 = Not at all willing to 7 = Highly willing) & &
\end{tabular}




\section{APPENDIX 2: Psychological influences on seaweed consumption - measurement scales and factor loadings}

\begin{tabular}{|c|c|c|c|c|c|}
\hline & F1: & F2: & F3: & F4: & F5: \\
\hline Responsibility/food safety (Alpha: 0.88 ): & & & & & \\
\hline $\begin{array}{l}\text { I am concerned about the conditions under which the } \\
\text { food I buy is produced }\end{array}$ & .836 & & & & \\
\hline $\begin{array}{l}\text { I try to choose food that is produced in a sustainable } \\
\text { way }\end{array}$ & .791 & & & & \\
\hline $\begin{array}{l}\text { I'm concerned about the amount of artificial additives } \\
\text { and preservatives in food }\end{array}$ & .780 & & & & \\
\hline $\begin{array}{l}\text { It is important to understand the environmental } \\
\text { impact of our eating habits }\end{array}$ & .741 & & & & \\
\hline $\begin{array}{l}\text { The quality and safety of food nowadays concerns } \\
\text { me }\end{array}$ & 697 & & & & \\
\hline Neophobic (Alpha: 0.85): & & & & & \\
\hline I only eat foods which are familiar to me & & .823 & & & \\
\hline I don't trust new foods & & .817 & & & \\
\hline I am afraid to eat things I have never had before & & .803 & & & \\
\hline Food from other cultures looks too weird to eat & & .776 & & & \\
\hline Health consciousness (Alpha: 0.85 ): & & & & & \\
\hline I'm usually aware of my health & & & .770 & & \\
\hline I reflect about my health a lot & & & .765 & & \\
\hline I'm very self-conscious about my health & & & .723 & & \\
\hline $\begin{array}{l}\text { I'm aware of the state of my health as I go through } \\
\text { the day }\end{array}$ & & & .685 & & \\
\hline Symbolic value (Alpha: 0.88 ): & & & & & \\
\hline $\begin{array}{l}\text { What and where someone eats, says something about } \\
\text { who they are as a person }\end{array}$ & & & & .866 & \\
\hline The food you eat is an expression of your personality & & & & .838 & \\
\hline You can tell a lot about a person, by what they eat & & & & .836 & \\
\hline Snacking behaviour (Alpha: 0.85): & & & & & \\
\hline I eat a lot of snacks rather than having set meal times & & & & & .856 \\
\hline $\begin{array}{l}\text { I tend to snack during the day, which often means I } \\
\text { am not hungry at mealtimes }\end{array}$ & & & & & .851 \\
\hline $\begin{array}{l}\text { I eat a lot of small meals rather than keeping to fixed } \\
\text { mealtimes }\end{array}$ & & & & & .834 \\
\hline
\end{tabular}




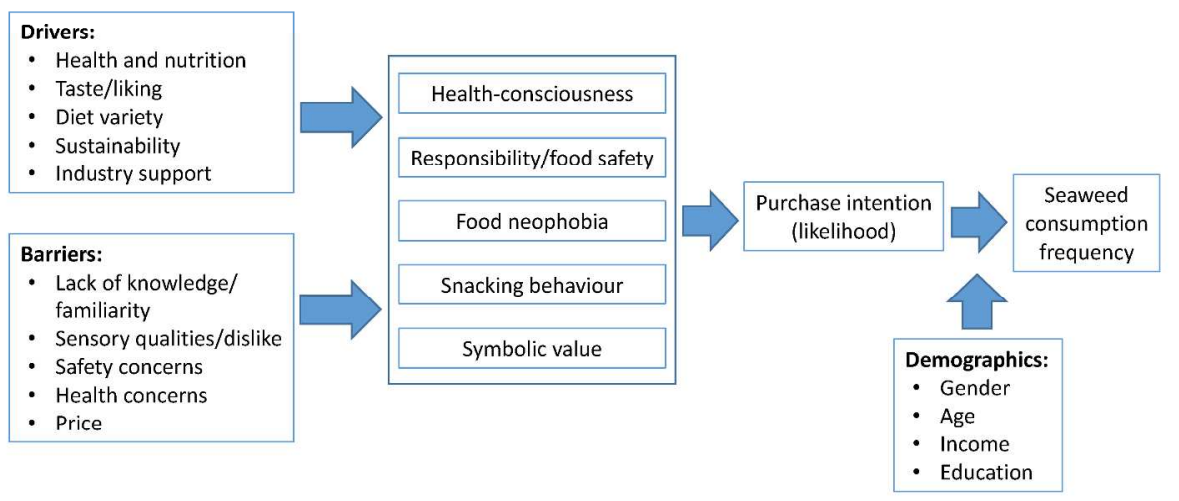

$297 \times 210 \mathrm{~mm}(300 \times 300 \mathrm{DPI})$ 